\title{
The Role of E-money on Business Growth in Indonesia
}

Submitted Date :

25 October 2021

Accepted Date :

22 November 2021

\author{
Harril Brimantyo* \\ University of Merdeka Malang \\ harril.brimantyo@unmer.ac.id \\ Agung Suwandaru \\ Western Sydney University \\ a.suwandaru@westernsydney.edu.au \\ Anandhayu Mahatma Ratri \\ University of Merdeka Malang \\ anandhayu.ratri@unmer.ac.id \\ Ginanjar Indra Kusuma Nugraha \\ University of Merdeka Malang \\ gim_revalin@unmer.ac.id \\ Muhammad Rizki Firdaus \\ University of Merdeka Malang \\ rizky.firdaus@unmer.ac.id
}

Suggested Citation:

Popovska-Kamnar, Neda. 2014. The Use Of Electronic Money And Its Impact On Monetary Policy. Journal of Contemporary Economic and Business Issues. Vol. 1 No.2, pp. 79-92. http://hdl.handle.net/10419/147460

Abstract:

The objective of this research are to analyze the differences in business growth in Indonesia before and after the e-money, era and to analyze the the role of e-money in business growth in Indonesia.The type of this research is quantitative with comparative and explanatory method. The data used in this research is e-money and Indonesia Composite Index (also known as IHSG). Data analysis technique used in this research are paired t-test and regression. The result shows that there is significant difference of business growth in Indonesia between before and after e-money era. Furthermore, based on regression analysis shows that e-money has significant effect on business growth in Indonesia.

Keywords : Business Growth, E-Money, Indonesia Composite Index

JEL Classification: E3

${ }^{*}$ Corresponding Author 


\section{Research Background}

The use of money as a legal medium of exchange is still the main transaction tool in business activities in Indonesia. Along with the times, the types of money developed into various kinds. One type of money that is growing rapidly at this time is electronic money or more commonly known as electronic money/e-money.

Bank Indonesia defines e-money as a means of payment that meets the elements, among others, issued on the basis of the value of money deposited in advance to the issuer, the value of money stored electronically in a medium such as a server or chip, and the value of electronic money managed by the issuer. is not a deposit as referred to in the law governing banking. The existence of e-money in Indonesia can be said to be quite long. It is proven that the use of e-money has been regulated in Bank Indonesia Regulation Number 11/12/PBI/2009 dated 13 April 2009 concerning Electronic Money and Bank Indonesia Circular Letter No. 11/11/DASP dated 13 April 2009 regarding Electronic Money (Electronic Money). (bi.go.id).

The ease of processing transactions using e-money is one of the reasons why e-money is so popular. The transaction process using e-money provides convenience and speed in practice. This is because the transaction process simply goes through the scanning process on the device that has been prepared. The nominal value of the transaction paid will be correct so that the seller does not need to provide change which often takes time, especially if the nominal fraction owned by the seller is not available. The use of e-money is also very applicable to mass transactions that have small value but have a high frequency.

The superiority of the transaction process using e-money makes the trend of using e-money increase. This is evidenced by data from Bank Indonesia which shows an increase in both the volume of transactions using e-money and the nominal transactions. The following is data related to the development of e-money in the last 5 years in Indonesia:

Table 1. The development of e-money (2015-2019)

\begin{tabular}{rrrrr} 
Year & \multicolumn{1}{c}{$\begin{array}{c}\text { Volume } \\
\text { (in transactions) }\end{array}$} & $\begin{array}{c}\text { Transaction } \\
\text { Growth (\%) }\end{array}$ & $\begin{array}{c}\text { Nominal } \\
\text { (in millon Rupiah) }\end{array}$ & Nominal Growth (\%) \\
\hline 2015 & $535,579,528$ & & $5,283,018$ & \\
2016 & $683,133,352$ & 27.55 & $7,063,689$ & 33.71 \\
2017 & $943,319,933$ & 38.09 & $12,375,469$ & 75.20 \\
2018 & $2,922,698,905$ & 209.83 & $47,198,616$ & 281.39 \\
2019 & $5,226,699,919$ & 78.83 & $145,165,468$ & 207.56 \\
\hline
\end{tabular}

Source : bi.go.id (data processed)

Table 1 shows that every year, both in terms of transaction volume and nominal, the performance of emoney in Indonesia continues to increase. The growth of e-money has increased rapidly in the last 2 years, namely in 2018 and 2019. This proves that many people are starting to use e-money as a transaction tool in their daily lives. The very fast growth of e-money is expected to accelerate business growth in Indonesia.

The increasing of the volume and nominal value of transactions by using e-money as a media of payment, followed by the increasement of e-money providers. In 2016, there are 21 e-money providers. In 2017, 6 new providers increased to 27. In 2018, there are 8 new providers added. In 2019, there were 45 e-money providers in Indonesia. (bi.go.id)

Competition for e-money service providers is not only due to the rising of e-money demand. Moreover, the Indonesian government also urges the public to move towards the era of a cashless society. This is stated in the National Non-Cash Movement which has been launched by the government since 2014. The use of e-money is expected to minimize the circulation of counterfeit money. In addition, it is also hoped that the use of e-money can increase the effectiveness and efficiency in transactions so that it can have a positive impact.

The effectiveness and efficiency of transactions using e-money can be achieved because payment transactions will be carried out more quickly. In addition, each e-money service provider also often provides special offers such as discounts and free vouchers for certain transactions. This condition will increase public consumption and of course will have a positive impact on business growth, especially in Indonesia.

Business growth in this reseach referred to in this study is the growth of company value in general in Indonesia. Business growth is inseparable from operational problems and the profitability of a company. Growth can be achieved if there is adequate profit earned on an ongoing basis. The company's management continues to strive to increase profits. Things that can be done by the company is to continue to develop the products offered and innovate in business operational processes. The increase in profit is also inseparable from the efforts 
to increase sales made by the company. The more products that can be sold by the company, assuming other factors are considered constant, the higher the profit earned by the company.

The company's success in increasing profits will have a positive impact on the value of the company which is reflected in the company's stock price. The higher the profit generated by the company, the higher the share price of the company. If its viewed as a general, the increase in company growth will be reflected in the Indonesia Compostie Index $(\mathrm{ICl})$. ICl is the overall index of all shares on the Indonesia Stock Exchange. The $\mathrm{ICl}$ has several benefits, among others, as a marker of market direction, a measure of profit levels, and as a benchmark for portfolio performance. The development of the $\mathrm{ICl}$ value can also be used to measure business growth in general in Indonesia.

If it is assumed that Indonesia is a closed economy, the increase in the use of non-cash payment instruments or e-money can have an impact on decreasing demand for money in the community. Theoretically, a decrease in the demand for money will cause a decrease in interest rates in the money market because people will choose to use non-cash payment instruments accompanied by saving money in the bank concerned (Mankiw, 2009). This makes borrowing costs more competitive, thereby increasing firm investment and increasing national real output. So it can be said that the use of e-money will be able to cause business growth so that it will have an impact on economic growth in a country.

Research on e-money has been studied by several researchers before. However, it is still rare for previous studies to try to find the relationship or role of e-money in business growth. Therefore, this study is also based on the findings of previous studies that examined e-money. Febrianty (2019) examines the influence of the non-cash payment system in the digital era on Indonesia's economic growth rate. Based on this research, it is known that the non-cash payment system consisting of the value of e-money transactions and the value of credit card transactions has a positive and significant influence on the level of economic growth.

Miliani, et al (2013) researched the Adoption Behavior of E-Money Usage. This study aims to determine the factors that influence the adoption behavior of e-money users and examine the differences in intentions to use/reuse e-money between adopters and non-adopters. The results of this study improve understanding of emoney adoption behavior by describing perceived benefits as a factor influencing intention to use/reuse electronic money in Indonesia.

Furthermore, Popovska-Kammar (2014) examined the use of electronic money and its impact on monetary policy. This study aims to determine the impact of using e-money on monetary policy, especially in European countries. The results of this study indicate that E-money has the potential to replace the circulating currency, which is part of the monetary aggregate of the central bank's balance sheet.

Thus, the researcher tries to examine more deeply the role of e-money, especially in business growth in Indonesia. Based on the explanation, the objective of this research are knowing and analyzing the differences of business growth in Indonesia before and after the use of e-money, and the the role of e-money in business growth in Indonesia.

\section{Research Method}

The type this research is quantitative with comparative and explanatory research approaches. The research was conducted by collecting secondary data in the form of volume data and nominal e-money transactions sourced from the official website of Bank Indonesia. In addition, the researcher also uses other secondary data, namely the Indonesia Composite Index (ICl) data obtained from the official website of the Indonesia Stock Exchange. The data analysis techniques used in this research are paired t-test and linear regression.

.Result

Since the beginning of the issuance of e-money in Indonesia, the development of publishing and using e-money has grown rapidly. The number of transactions using e-money by the public continues to increase, followed by the nominal amount of e-money used. Table 2 shown the data regarding the development of e-money from 20162019.

Tabel 2. Nominal Amount of e-money Transactions in Indonesia (In Million Rupiah)

\begin{tabular}{rrrrr}
\hline Month & 2016 & 2017 & 2018 & 2019 \\
January & 387,404 & 665,791 & $3,491,803$ & $5,817,363$
\end{tabular}


Volume 6, № 1 (xx), 2019

\begin{tabular}{lrrrr}
\multicolumn{1}{c}{ Month } & \multicolumn{1}{c}{2016} & \multicolumn{1}{c}{2017} & \multicolumn{1}{c}{2019} \\
\hline February & 519,364 & 812,282 & $3,360,791$ & $5,970,262$ \\
March & 492,166 & 746,397 & $3,458,627$ & $8,956,978$ \\
April & 515,232 & 633,561 & $3,352,894$ & $10,671,171$ \\
May & 587,052 & 879,108 & $3,534,569$ & $12,815,686$ \\
June & 673,151 & $1,019,650$ & $3,469,727$ & $11,874,500$ \\
July & 561,862 & $1,141,504$ & $3,582,677$ & $12,939,443$ \\
August & 616,484 & 790,699 & $3,899,474$ & $12,878,103$ \\
September & 5449,16 & 817,366 & $3,517,835$ & $13,820,413$ \\
October & 584,319 & $1,264,462$ & $4,448,574$ & $16,370,715$ \\
November & 831,972 & $1,647,358$ & $5,195,495$ & $16,080,701$ \\
December & 749,766 & $1,957,290$ & $5,886,152$ & $16,970,133$ \\
Total & $7,063,689$ & $12,375,469$ & $47,198,616$ & $145,165,468$ \\
Growth & - & $75.19 \%$ & $281.33 \%$ & $207.59 \%$ \\
\hline
\end{tabular}

Source : bi.go.id processed (2020)

Based on table 2 above, it can be concluded that the use of e-money is increasing from year to year. A clear difference was found in 2017 and 2018 where the nominal number of transactions increased by $281.33 \%$. It caused by the digital era is growing rapidly where there are already many online marketplaces such as Tokopedia, Shopee, Lazada, and so on. In addition, the emergence of online transportation modes such as Gojek and Grab has also contributed to changing the habits of people who used to still use physical money a lot as a transaction tool into electronic money. This very high difference is the basis for researchers in determining the cut-off point as the basis for comparison of the era of e-money use.

Furthermore, data on business growth in Indonesia can be seen through the Indoensia Composite Index $(\mathrm{ICl})$. The rise and fall of the $\mathrm{ICl}$ can reflect business conditions in Indonesia in general. The following is data on the development of the ICI in Indonesia in 2016-2019.

Table 3. Indonesia Composite Index in 2016-2019 (In Rupiah)

\begin{tabular}{lrrrr}
\multicolumn{1}{c}{ Month } & \multicolumn{1}{c}{2016} & \multicolumn{1}{c}{2018} & \multicolumn{1}{c}{2019} \\
\hline January & $4,770.81$ & $5,386.69$ & $6,597.22$ & $6,443.35$ \\
February & $4,845.23$ & $5,568.11$ & $6,188.99$ & $6,468.75$ \\
March & $4,838.44$ & $5,685.3$ & $5,994.6$ & $6,455.35$ \\
April & $4,796.73$ & $5,738.15$ & $5,983.59$ & $6,209.12$ \\
May & $5,016.5$ & $5,829.71$ & $5,799.24$ & $6,358.63$ \\
June & $5,215.84$ & $5,840.94$ & $5,936.44$ & $6,390.5$ \\
July & $5,385.92$ & $5,864.06$ & $6,018.46$ & $6,328.47$ \\
August & $5,364.65$ & $5,900.85$ & $5,976.55$ & $6,169.1$ \\
September & $5,422.38$ & $6,005.78$ & $5,831.65$ & $6,228.32$ \\
October & $5,148.91$ & $5,952.14$ & $6,056.12$ & $6,011.83$ \\
November & $5,296.71$ & $6,355.65$ & $6,194.5$ & $6,299.54$ \\
December & $5,294.1$ & $6,605.63$ & $6,532.97$ & $5,940.05$ \\
Average & $5,116.35$ & $5,894.42$ & $6,098.53$ & $6,275.25$ \\
\hline
\end{tabular}

Source : idx.co.id processed (2020)

Based on table 3, it can be seen that the $\mathrm{ICl}$ value has increased from year to year. On average in every year, the value of the $\mathrm{ICl}$ has never decreased. In the era of using e-money, the value of the $\mathrm{ICl}$ reach six thousand rupiah and continued to increase over time. Therefore, it is necessary to conduct further research regarding the relationship between the use of e-money and business growth in Indonesia.

The inferential analysis in this study divided into two, comparative test and the effect test. The comparative test in this study was carried out by using a paired t-test. Before carrying out the paired t-test, the normality test was carried out first as a prerequisite for the paired t-test. The following are the results of the normality test using the Kolmogorov Smirnoff method.

Table 4. Normality Test with Kolmogorov-Smirnov Method

\begin{tabular}{llrr} 
& & Before & \multicolumn{1}{c}{ After } \\
\hline N & & 24 & 24 \\
Normal Parameters & Mean & 5505,3846 & 6183,8892 \\
& Std. Deviation & 488,66977 & 229,39215
\end{tabular}


Most Extreme Differences

Test Statistic

Asymp. Sig. (2-tailed)
Absolute

Positive

Negative

\begin{tabular}{rr}
, 109 &, 140 \\
, 109 &, 140 \\
,- 080 &,- 079 \\
, 109 &, 140 \\
, 200 &, 200 \\
\hline
\end{tabular}

Source : Data Processed (2020)

Based on table 4, it can be concluded that the data used in this study is normally distributed. This can be seen from the Asymp value. Sig where both the value before and after the e-money era is above the alpha value, which is 0.05 . Therefore, this research can be continued for different tests using the paired t-test method. The following are the results of the paired t-test in this study.

Table 5. Paired Sample Test

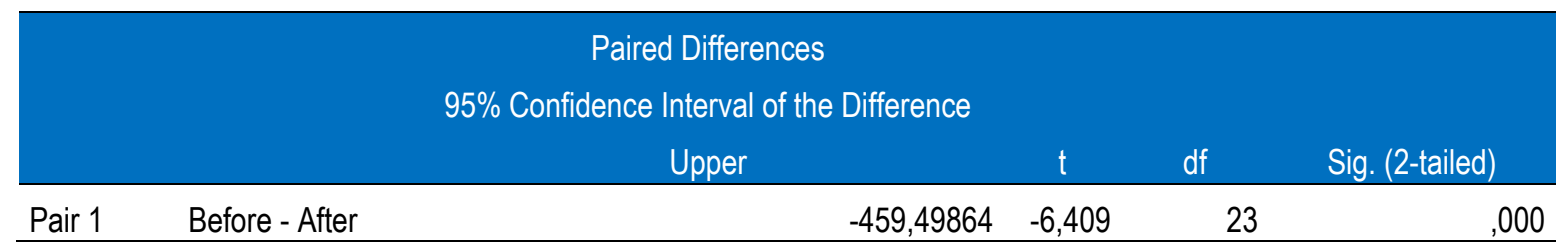

Source : Data Processed (2020)

Based on table 5 above, it can be concluded that there is a significant difference in the $\mathrm{ICl}$ value between before and after the e-money era in Indonesia. This can be seen in the sig column, where the sig value for the paired ttest results is below the alpha value, which is 0.05 . This real difference strengthens the researcher's assumption that there is a role for e-money in business growth in Indonesia. Therefore, the researchers conducted further analysis to determine and analyze the relationship or influence of e-money on business growth in Indonesia.

The effect test was carried out using simple regression analysis. The variables in the simple regression analysis in this study are E-money as the independent variable and Business Growth which is proxy by the Indoensia Composite Index $(\mathrm{ICl})$ as the dependent variable. The following are the results of the simple regression test in this study.

Table 6. Model Summary

\begin{tabular}{lrrrrr} 
Model & $\mathrm{R}$ & $\mathrm{R}$ Square & $\begin{array}{c}\text { Adjusted R } \\
\text { Square }\end{array}$ & $\begin{array}{c}\text { Std. Error of the } \\
\text { Estimate }\end{array}$ \\
\hline 1 & .556 & .309 & & .294 & 428,681 \\
\hline
\end{tabular}

Source : Data Processed (2020)

Based on table 6 , it can be seen that the value of $R^{2}$ is 0.309 or $30.9 \%$. This means that e-money contributes to Business Growth by $30.9 \%$. This value is quite high because e-money is one of the other variables which not examined in this study, which contributed $69.1 \%$. Furthermore, it is necessary to examine the effect of E-money on Business Growth in Indonesia. Table 7 shown the results of the t-test in this research.

Table 7. Coefficient

\begin{tabular}{|c|c|c|c|c|c|c|}
\hline \multirow{2}{*}{\multicolumn{2}{|c|}{ Model }} & \multicolumn{2}{|c|}{ Unstandardized Coefficients } & \multirow{2}{*}{$\begin{array}{l}\text { Standardized } \\
\text { Coefficients } \\
\text { Beta }\end{array}$} & \multirow[b]{2}{*}{$t$} & \multirow[b]{2}{*}{ Sig. } \\
\hline & & B & Std. Error & & & \\
\hline & (Constant) & 5595,636 & 82.751 & & 67.620 & .000 \\
\hline & E-money & 5,643 & .000 & .556 & 4.532 & .000 \\
\hline
\end{tabular}

Source : Data Processed (2020)

Based on table 7, it can be seen that E-money has a positive effect on Business Growth. This is reflected in the positive beta coefficient value of 5.643. Thus, it can be concluded that the increase in E-money will be followed by an increase in Business Growth. Furthermore, it is also known that E-Money has a significant effect on 
Business Growth. This is reflected in the significance value where the significance value obtained is 0.000 where the value is lower than the alpha value, which is 0.05 . Thus it can be concluded that the results of this study indicate that E-money has a positive and significant effect on Business Growth.

\section{Discussion}

\section{The Differences of Business Growth Before and After the E-money Era}

Based on the results of the research, it is known that there are significant differences regarding Business Growth in Indonesia between before and after the E-money era. This is in accordance with the description that has been explained by the researcher on the reseach background which states that the use of E-money can increase effectiveness and efficiency within the company. The effectiveness and efficiency have a positive impact so that the company can increase its profitability. An increase in the company's profitability will be responded positively by investors so that the stock price in the market tends to rise.

Before the era of e-money, both buyers and sellers conducted transactions conventionally using physical money. The transaction takes a long time considering that there are several weaknesses in physical transactions. Furthermore, the seller also needs to deposit the money into the bank by making a cash deposit. The presence of e-money can overcome the problems posed by conventional transactions. Transactions can occur faster, and sellers do not need to make cash deposits to the bank because the circulation of money occurs digitally and directly between user accounts. Effectiveness and efficiency can be directly felt both from the side of the buyer and seller.

In addition, the E-Money era also has other impacts besides increasing the effectiveness and efficiency of the company. The increase in the use of e-money can have an impact on a decrease in the demand for money in the community. Theoretically, a decrease in the demand for money will cause a decrease in interest rates in the money market because people will choose to use non-cash payment instruments accompanied by saving money in the bank concerned (Mankiw, 2009). This makes borrowing costs more competitive, thereby increasing corporate investment and increasing national real output. So it can be said that the use of e-money will lead to economic growth or in this case is business growth. So it can be concluded that the results of this study confirm the opinion of Mankiw (2009).

\section{The Effect of E-money on Business Growth}

Based on the results, it can be concluded that E-money has a positive and significant effect on Business Growth. This means that the higher nominal transactions using e-money will have a positive and significant impact on the increasing of Business Growth in Indonesia. The effectiveness of the use of e-money can increase the speed of transactions in the company. Efficiency from the use of e-money can cut the costs that must be incurred when using conventional transactions.

The presence of a digital marketplace is also increasingly supporting transactions that use e-money as a means of payment. From the seller's point of view, the company can cut a lot of costs such as the cost of renting a place, the cost of employee salaries, and other costs associated with conventional transactions. Thus, it can be concluded in general that E-money plays an important role in Business Growth in Indonesia

\section{Conclusion}

Based on the results of the research that has been done, it can be concluded that the results of this study are that there are significant (significant) differences regarding business growth in Indonesia before and after the use of e-money. In addition, it is also known that E-money has a positive and significant effect on business growth in Indonesia. Based on the conclusion of the study, the researcher can give some suggestions. For companies, given its positive impact on both the company and business growth in general, digital transactions need to be implemented and carried out massively because they are proven to increase effectiveness and efficiency. For the government, it is necessary to encourage the use of e-money to the public to help business growth and the country's economy.

Finally, for further researchers to be able to add variables and research objects. This research is general in nature and can still be developed by adding other variables that have not been studied or mediating variables that link e-money with business growth. In addition, this research does not cover micro, small and medium enterprises (MSMEs) which also use e-money in their transactions. 


\section{References}

Febrianty, Hastina. 2019. Pengaruh Sistem Pembayaran Non Tunai Dalam Era Digital Terhadap Tingkat Pertumbuhan Ekonomi Indonesia. Prosiding Festival Riset IImiah Manajemen \& Akuntansi, HIm. 306-313. ISSN : 2614-6681

Mankiw N,Gregory. 2009. Macroeconomics, 7th Edition. New York: Worth Publishers

Miliani, Lani., Purwanegara, Mustika Sufiati dan Indriani, Mia Tantri Diah. 2013. Adoption Behavior of E-Money Usage. Information Management and Business Review. Vol. 5 No. 7, pp 369-378. ISSN 2220-3796

Peraturan Bank Indonesia Nomor: 11/12/PBI/2009

Peraturan Bank Indonesia Nomor: 18/ 17/PBI/2016

Popovska-Kamnar, Neda. 2014. The Use Of Electronic Money And Its Impact On Monetary Policy. Journal of Contemporary Economic and Business Issues. Vol. 1 No.2, pp. 79-92. http://hdl.handle.net/10419/147460

Surat Edaran Bank Indonesia No.11/11/DASP/2009

www.bi.go.id 